http://jmscr.igmpublication.org/home/ ISSN (e)-2347-176x ISSN (p) 2455-0450 crossref DOI: https://dx.doi.org/10.18535/jmscr/v9i9.27

\title{
Profile of COPD in relation to Lung Function \& Smoking Status in a Tertiary Care Hospital in South India: A Cross Sectional Study
}

\author{
Authors \\ Dr Shahzad Hussain Arastu ${ }^{1^{*}}$, Dr Hidayath Hussain ${ }^{2}$, Dr Naresh Kumar Rao P $\mathbf{P}^{\mathbf{3}}$ \\ ${ }^{1}$ Assistant Professor, Department of Pulmonary Medicine, Shadan Institute of Medical Sciences. Hyderabad, \\ India \\ ${ }^{2}$ Professor, Department of Pulmonary Medicine, Shadan Institute of Medical Sciences Hyderabad, India \\ ${ }^{3}$ Post graduate Department of Pulmonary Medicine, Shadan Institute of Medical Sciences. Hyderabad, India \\ *Corresponding Author \\ Dr Shahzad Hussain Arastu
}

\begin{abstract}
COPD (Chronic Obstructive Pulmonary disease), is a chronic lung disease which is effects the small airways leading to limitation of airflow, causing progressive respiratory symptoms like cough, sputum production, wheezing, shortness of breath. Most important risk factors are smoking, environmental pollution and biomass fuel exposure. Prevalence of COPD is on the rise. Early diagnosis and treatment is needed to improve the quality of life and prevent exacerbations. In this study we have classified COPD according to $G O L D^{2}$ (Global initiative for chronic Obstructive Lung Disease) guidelines and comparing the lung functions of different age groups with their pack years of smoking.

Keywords: COPD, FEV1, FEVI/FVC, GOLD grading and assessment.
\end{abstract}

\section{Introduction}

COPD is the third leading cause of death worldwide, responsible for $75.6 \%$ of chronic respiratory disease DALY'S (Disability adjusted life years).Number of cases in India increased from 28.1 million in 1990 to 55.3 million in 2016, an increase in prevalence from $3.3 \%$ to $4.2 \%$ ${ }^{1}$.Prevention and control of the disease is the need of the hour. On average moderate to heavy smoker has a $15 \mathrm{ml} / \mathrm{yr}$ larger decline of FEV1 than non smokers ${ }^{12}$. Assessment of COPD according to severity and GROUP A to D(GOLD) leads to proper management and prevention of complications in this study.

\section{Material \& Methods}

The patients attending the department and having symptoms and radiology suggestive of COPD were subjected to the Spirometry test from a period of NOV 2015-OCT 2017 Out of these 236 cases were found to have COPD (GOLD Guidelines).

\section{Inclusion Criteria}

Age more than $40 \mathrm{yrs}$ \{study period November 2015 - October 2017\}.

Clinical, radiological and pulmonary function test correlation for diagnosis according to GOLD criteria. 


\section{JMSCR Vol||09||Issue||09||Page 167-173||September}

Exclusion Criteria: Other obstructive lung diseases like Asthma, Bronchiectasis, Asthma COPD overlap syndrome

\section{Data Analysis}

The following observations were made out of 236 cases $84 \%$ were males \& $16 \%$ females.

\section{Age Distribution}

Most of the cases were in the age group of 61-70 years, followed by $27 \%$ in the 51-60 age brackets.

\section{Risk Factors}

$74 \%$ of the cases had smoking history, $26 \%$ mostly females had exposure to biomass fuel with history of cooking using firewood. Other risk factors like Passive smoking, environmental pollution.

Table 1 FEV1 Staging

\begin{tabular}{|l|c|c|c|c|}
\hline $\begin{array}{l}\text { MILD,N=12 } \\
\text { FEV1>80\% }\end{array}$ & $\begin{array}{c}\text { MODERATE,N=82 } \\
\text { FEV1 =50-79\% }\end{array}$ & $\begin{array}{c}\text { SEVERE,N=93 } \\
\text { FEV1=30-49\% }\end{array}$ & $\begin{array}{c}\text { VERY SEVERE,N=49 } \\
\text { FEV1 <30\% }\end{array}$ & TOTAL 236 \\
\hline 12 & 82 & 93 & 49 & \\
\hline $5 \%$ & $34.74 \%$ & $39.40 \%$ & $20.76 \%$ & \\
\hline
\end{tabular}

Majority of the cases had severe airflow obstruction with FEV1 OF 30-49\% OF predicted followed by moderate obstruction.

\section{Severity Assessment according to Gold}

IN this study most of the patients belong to the Group B \& GROUP D class signifies that more symptomatic patients seek hospital visit.
Specifically GROUP D about 91 OUT of 236 patients presented with exacerbation of COPD with ICU admission, significant risk of morbidity and mortality.

\section{Mean Flow Rates:}

Table 2 Mean Values

\begin{tabular}{|c|c|c|}
\hline Test & Range & Mean \\
\hline FVC $($ lt $)$ & $1.03-3.21$ & $2.22 \pm 0.5$ \\
\hline FEV1 (lt) & $0.53-1.84$ & $1.12 \pm 0.34$ \\
\hline FEV1\% & $25.70-77.0$ & $49.76 \pm 14.25$ \\
\hline FEV1/FVC & $21.5-70$ & $53.01 \pm 14.22$ \\
\hline
\end{tabular}

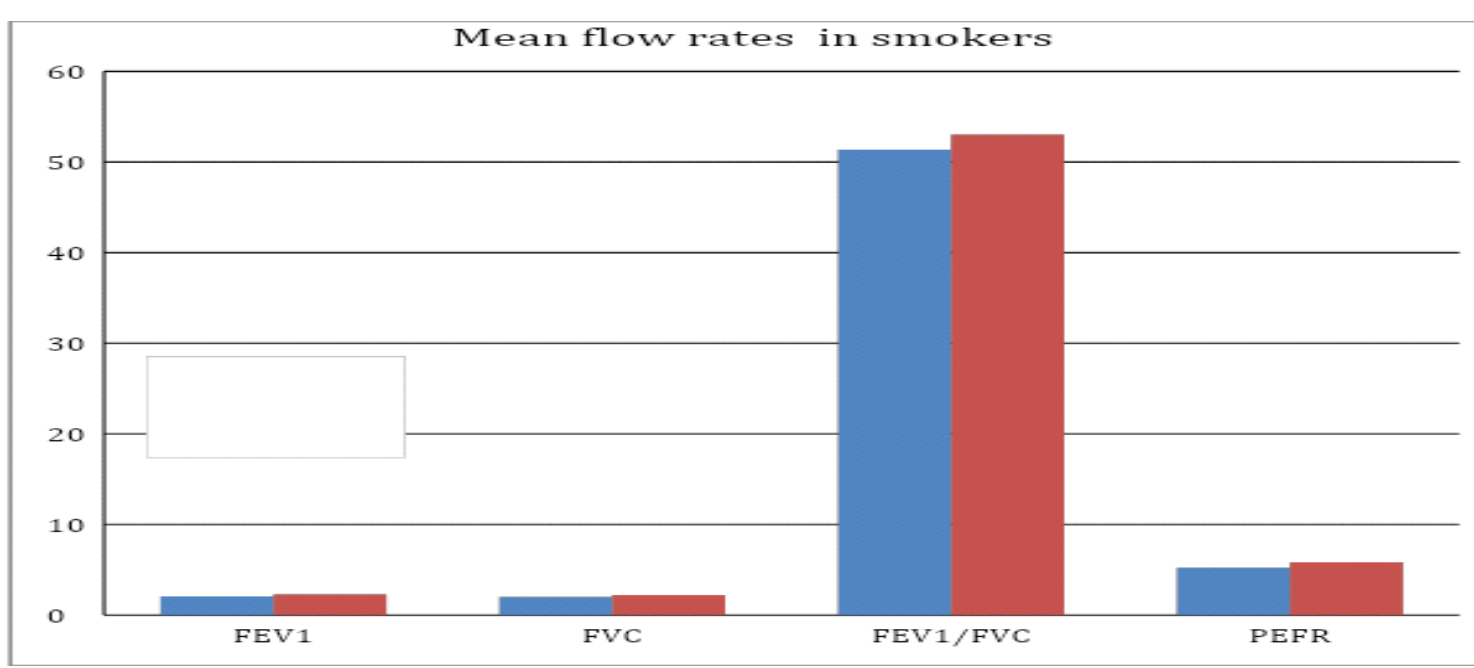

About 55\% had FEV1/FVC RATIO of 51 to $70 \%$. 
Table 3 FEV1/FVC \%Values

\begin{tabular}{|l|c|c|c|}
\hline FEV1/FVC & NUMBER & PERCENT & MEAN \\
\hline $61-70 \%$ & 68 & 29 & 65.6 \\
\hline $51-60 \%$ & 62 & 26 & 55.9 \\
\hline $41-50 \%$ & 36 & 15 & 44.9 \\
\hline $31-40 \%$ & 47 & 20 & 37.12 \\
\hline $21-30 \%$ & 15 & 6 & 25.6 \\
\hline $10-20 \%$ & 8 & 3 & 5.21 \\
\hline
\end{tabular}

Table 4 Pack Years of Smoking

\begin{tabular}{|l|c|c|}
\hline PACK YEARS & NUMBER & \% PERCENTAGE \\
\hline $1-10$ YRS & 6 & 2.54 \\
\hline $11-20 Y S$ & 28 & 11.86 \\
\hline $21-30$ YRS & 66 & 27.96 \\
\hline $31-40 Y S$ & 87 & 36.86 \\
\hline $41-50$ YRS & 24 & 10.16 \\
\hline$>50$ & 25 & 10.59 \\
\hline
\end{tabular}

In this study $66.36 \%$ had $21-40$ pack years of smoking history.

Significant decline in the lung function as the pack years of smoking increases.

Table 5 Comparison of Pack Years with Flow Values

\begin{tabular}{|l|c|c|c|}
\hline Duration of smoking & \multicolumn{3}{|c|}{ Percent predicted (mean \%) } \\
\hline (pack yrs) & FEV1 & FVC & PEFR \\
\hline $1-10$ yrs & 77.4 & 81 & 75.6 \\
\hline $11-20 \mathrm{yrs}$ & 70.6 & 73.6 & 64.6 \\
\hline $21-30$ & 68.3 & 72.3 & 63.6 \\
\hline $31-40$ & 64 & 70.7 & 60.5 \\
\hline $41-50$ & 59.9 & 68.3 & 58.9 \\
\hline$>50$ yrs & 58.25 & 65.8 & 56.75 \\
\hline
\end{tabular}

\section{Results}

In the present study Mean age was $63.16 \pm 10.45$.

Male predominant $84 \%$ and $74 \%$ smokers.

Common in Non- smoking females exposed to biomass fuel.

Present study shows majority of patients $\mathbf{3 9 . 4 0 \%}$ had FEV1 between 30-49\% (GOLD)Mean 49\%, belong to Severe degree of airflow obstruction. Most of the patients belong to GROUP D $(\mathrm{N}=91,38.55 \%) \quad$ and GROUP $\mathrm{B}(\mathrm{N}=68,28.81 \%)$,GROUP D+GROUP $\mathrm{B}(\mathrm{N}=159$, 67.37\%) implies that more symptomatic patients seek medical attention.

In this study GOLD CLASSIFICATION GROUP $\mathrm{C}(\mathrm{N}=45)$ and GROUP D $(\mathrm{N}=91)$, TOTAL $\mathrm{N}=136$, $\mathbf{5 7 . 6 2 \%}$ patients had increased risk of exacerbations.

We recommend that COPD patients should seek medical care earlier with regular follow up, smoking cessation, Pneumococcal and $\mathrm{H}$. influenza vaccination and pulmonary rehabilitation significantly improves the quality of life.

- The actual values of FVC (2.22 ltrs \pm 0.5), FEV1 (1.12 ltrs \pm 0.34),FEV1\% mean 49\% ratio of FEV1/ FVC Mean 53\% and PEFR are decreased more with increase in duration of smoking and increase in number of cigarettes per day. Thus showing a dose response relationship.

\section{Discussion}

In this study patients attending the department > 40yrs \{from November 2015 - October 2017\} were taken, COPD is detected based on history, physical examination, radiological picture and spirometry (GOLD guidelines) about 236 cases were studied.

COPD is a disease of late adulthood. As the age advances the lung function (FEV1) declines and 
other risk factors add to the disease process. In the present study mean age was $63.16 \pm 10.45$, which is compared to Gareth james et $\mathrm{al}^{16}$ mean age $71 \mathrm{yrs}$, Holm $\mathrm{KE}^{17}$ study mean age 59.9 yrs and S.M.Afonsa ${ }^{18}$ mean age group 40-59 yrs.

COPD is a male dominant disease, the high prevalence in males which is due to higher prevalence of smoking. Present study $74 \%$ are male and $26 \%$ females. All female non- smokers had history of cooking with burning wood or cow dung (Biomass fuel) ${ }^{14}$.

Present study consists of mean value of FEV1 1.12 (ltrs) \pm 0.34 , FVC (ltrs) $2.22 \pm 0.50$ and FEV1/FVC\% 53.01\% \pm 14.22. According to GOLD criteria ${ }^{2}$ majority of the patients in the present study belong to moderate to severe airflow obstruction. Most of the patients belonged to the Group D (GOLD CLASSIFICATION) followed by GROUP B, suggest that most COPD patients seek medical attention when there are more symptomatic and in advanced stage of disease, leading to increased risk of complications like recurrent exacerbations, respiratory failure, cardiovascular events.

Present study shows $\mathbf{3 9 . 4 0 \%}$ of patients had FEV1 between 30-49\%(GOLD)stage3, majority of the patient in present study belong to severe degree of airflow obstruction, which was in contrast to Niranjan Mambally et $\mathrm{al}^{15}$ most had stage 2 GOLD disease. Comparable to Maria Jose et $\mathrm{al}^{19}$ mean FEV1 41\%. Mean flow rates of smokers were, baseline FEV1 $2.07 \pm 0.25 \&$ post dilator was $2.3 \pm 0.35$; FVC, $1.99 \pm 2.53$ was the baseline rate and $2.22 \pm 0.5$ post dilator. $\mathrm{PEF}$ was $5.21 \pm 3.51$ against $5.83 \pm 0.81$ post dilator. FEV1/FVC was $51.35 \pm 3.42$ while post dilator was $53.01 \pm 14.2$.

In our study there was a statistically significant decrease in the levels of FEV1, FVC, FEV1/FVC and PEFR $^{\text {TABLE } 5}$ more with an increase in duration of smoking and also with the increase in the number of cigarettes smoked per day i.e. pack years. Similar findings were also reported in studies, Miller $\mathrm{A}$ et $\mathrm{al}^{29}, \& \mathrm{M}$ hase $\mathrm{VT}$ et $\mathrm{al}^{32}$.
Our findings suggest a decrease in lung functions in the first five years of smoking and is similar to the finding of Camilli $\mathrm{AE}$ et $\mathrm{al}^{25}$ suggesting that the earliest effects of smoking are relatively rapid. As shown by other studies such as Tashkin DP et $\mathrm{al}^{24}$, Dockery DW et $\mathrm{al}^{26}$, and Gorecka et $\mathrm{al}^{34}$, that quitting smoking improves the lung function. Hence the inflammatory changes in small airways often reverse with cessation of smoking.

\section{References}

1. The burden of chronic respiratory diseases and their heterogeneity across the states of India: the Global Burden of Disease Study 1990-2016, LANCET, VOLUME 6, ISSUE 12, E1363-E1374, DECEMBER 01, 2018.

2. Global Initiative for Chronic Obstructive Lung Diseases 2020 report, http://goldcopd.org.

3. Jindal SK. Emergence of chronic obstructive pulmonary disease as an epidemic in India. Indian J Med Res. 2006 Dec;124(6):619-30. PMID: 17287549.

4. McKay AJ, Mahesh PA, Fordham JZ, Majeed A. Prevalence of COPD in India: a systematic review. Prim Care Respir J. 2012 Sep;21(3):313-21. doi: 10.4104/pcrj.2012.00055. PMID: 22790612 ; PMCID: PMC6547954.

5. Salvi S, Agrawal A. India needs a national COPD prevention and control programme. J Assoc Physicians India. 2012 Feb;60 Suppl:5-7. PMID: 23155805.

6. Gupta D, Agarwal R, Aggarwal AN, et al. Guidelines for diagnosis and management of chronic obstructive pulmonary disease: Joint ICS/NCCP (I) recommendations. Lung India. 2013;30(3):228-267. doi:10.4103/0970-2113.116248

7. The Prevalence of Chronic Obstructive Pulmonary Disease and the Determinants of Underdiagnosis in Women Exposed to Biomass Fuel in India- a Cross Section 
Study, Chonnam Med J. 2016 May;52(2):117-122.

8. B. Brashier, J. Londhe, S. Madas, V. Vincent and S. Salvi, "Prevalence of SelfReported Respiratory Symptoms, Asthma and Chronic Bronchitis in Slum Area of a Rapidly Developing Indian City," Open Journal of Respiratory Diseases, Vol. 2 No. 3, 2012, pp. 73-81. doi: 10.4236/ojrd.2012.23011.

9. Evaluation of COPD Longitudinally to Identify Predictive Surrogate End-points (ECLIPSE) J. Vestbo, W. Anderson, H. O. Coxson, C. Crim, F. Dawber, L. Edwards, G. Hagan, K. Knobil, D. A. Lomas, W. MacNee, E. K. Silverman, R. TalSinger,European Respiratory Journal 2008 31: 869-873; $\quad$ DOI: 10.1183/09031936.00111707

10. TORCH (TOwards a Revolution in COPD Health) survival study protocol,European Respiratory Journal 2004 24: 206-210; DOI: 10.1183/09031936.04.00120603

11. Thomas ET, Guppy M, Straus SE, et al. Rate of normal lung function decline in ageing adults: a systematic review of prospective cohort studies. BMJ Open 2019;9:e028150. doi:10.1136/ bmjopen2018-028150

12. Kerstjens HA, Rijcken B, Schouten JP, Postma DS. Decline of FEV1 by age and smoking status: facts, figures, and fallacies. Thorax. 1997 Sep;52(9):820-7. doi: $\quad 10.1136 /$ thx.52.9.820. PMID: 9371217; PMCID: PMC1758654.

13. Franssen FM, Han MK. "The ABC of GOLD A-B-C-D". Eur Respir J. 2013 Nov;42(5):1166-8. doi: 10.1183/09031936.00107813. PMID: 24178929.

14. Johnson P, Balakrishnan K, Ramaswamy $\mathrm{P}$, et al. Prevalence of chronic obstructive pulmonary disease in rural women of Tamilnadu: implications for refining disease burden assessments attributable to household biomass combustion. Glob Health Action. 2011;4:7226. doi:10.3402/gha.v4i0.7226

15. A correlative study of spirometric parameters and ECG changes in patients with chronic obstructive pulmonary disease, Niranjan Mambally Rachaiah et.al / Int J Biol Med Res. 2012; 3(1):13221326

16. James, G., Donaldson, G., Wedzicha, J. et al. Trends in management and outcomes of COPD patients in primary care, 2000 2009: a retrospective cohort study. npj Prim Care Resp Med 24, 14015 (2014). https://doi.org/10.1038/npjpcrm.2014.15

17. Holm KE, Plaufcan MR, Ford DW, et al. The impact of age on outcomes in chronic obstructive pulmonary disease differs by relationship status. J Behav Med. 2014;37(4):654-663. doi:10.1007/s10865013-9516-7

18. Ana S.M. Afonso, Katia M.C. Verhamme, Miriam C.J.M. Sturkenboom, Guy G.O. Brusselle, COPD in the general population: Prevalence, incidence and survival, Respiratory Medicine,Volume 105, Issue 12,2011,Pages 1872-1884

19. María José Espinosa de los Monteros, Carolina Peña, Enrique Javier Soto Hurtado, Javier Jareño, Marc Miravitlles, Variability of Respiratory Symptoms in Severe COPD, Archivos de Bronconeumología (English Edition), Volume 48, Issue 1,2012,Pages 3-7,ISSN 1579-2129

20. Association between Functional Small Airway Disease and FEV1 Decline in Chronic Obstructive Pulmonary Disease Surya P Bhatt et al Am J Respir Crit Care Med 2016 Jul 15;194(2):178-84. doi: 10.1164/rccm.201511-2219OC.

21. Sinha DN, Gupta PC, Pednekar MS. Tobacco use in a rural area of Bihar. Indian J Community Med 2003;28(4): 1012 
22. Behera D, Sood P, Singh S. Passive smoking, domestic fuels and lung function in North Indian Children. Indian J Chest Dis Allied Sci 1998;40:89-98.

23. Jindal SK, Gupta D. Environmental tobacco smoke and asthma. Indian J Chest Dis Allied Sci 1995;37(4):203-07.

24. Tashkin DP, Clark VA, Coulson AH, Simmons M, Bourque B, Reems C et al. The UCLA Population Studies of Chronic Obstructive Respiratory Disease- Effect of smoking on lung function: A prospective study of a free living population. Am Rev Respir Dis 1984;130:707

25. Camilli AE, Burrows B, Knudson RJ, Lyle SK, Lebowitz MD. Longitudinal changes in Forced Expiratory Volume in One Second in Adults-Effect of smoking and smoking cessation. Am Rev Respir Dis 1987;135:794-99

26. Dockery DW, Speizer FE, Ferris BG, Ware JH, Louis TA, Spiro A. Cumulative and reversible effects of lifetime smoking on simple tests of lung function in adults. Am Rev Respir Dis 1988;137: 286-92.66

27. Walter S, Jeyaseelan L. Impact of cigarette smoking on pulmonary function in nonallergic subject. National Med J Ind 1992;5(5):211-13

28. Anthonisen NR, Connett JE, Kiley JP, Altose MD, Bailey WC, Buist AS et al. Effects of smoking intervention and the use of an inhaled anticholinergic bronchodilator on the rate of decline of FEV1. JAMA 1994;272 (19):1497-504.

29. Miller A, Lilis P, Godbold J, Chan E, Wu $\mathrm{X}$, Selikoff I J. Spirometric Impairments in long-term insulators relationships of duration of exposure, smoking and radiographic abnormalities. Chest 1994;105:175-82.

30. Sandvik L, Erikssen G, Thaulow E. Long term effects of smoking on physical fitness and lung function: a longitudinal study of
1393 middle aged Norwegian men for seven years. BMJ 1995 ;311:715-17.67

31. Chhabra SK, Rajpal S, Gupta R. Patterns of smoking in Delhi and comparison of chronic respiratory morbidity among beedi and cigarette smokers. Indian J Chest Dis Allied Sci 2001;43:19-26.

32. Mhase VT, Reddy PSN. Effect of smoking on lung functions of workers exposed to dust and fumes. Indian $\mathbf{J}$ Com Med 2002;27(1):26-29.

33. Prasad BK, Sahay AP, Singh AK. Smoking women and their function tests. Kathmandu University Med J 2003;2(2):142-44.

34. Gorecka D, Bednarek M, Nowinski A, Puscinska E, Goljan-Geremek A, Zielinski J. Diagnosis of airflow limitation combined with smoking cessation advice increases stop-smoking rate. Chest 2003;123:1916-23.

35. Shahab I, Jarvis MJ, Britton J, West R. Prevalence, diagnosis and relation to tobacco dependence of chronic obstructive pulmonary disease in a nationally representative population sample. Thorax 2006;61:1043-47.

36. Kuwal A, Joshi V, Dutt N, Singh S, Agarwal KC, Purohit G. A Prospective Study of Bacteriological Etiology in Hospitalized Acute Exacerbation of COPD Patients: Relationship with Lung Function and Respiratory Failure. Turk Thorac J. 2018 Jan;19(1):19-27. doi: 10.5152/TurkThoracJ.2017.17035. Epub 2017 Nov 29. PMID: 29404182; PMCID: PMC5783049.

37. Cukic V, Lovre V, Dragisic D, Ustamujic A. Asthma and Chronic Obstructive Pulmonary Disease (COPD)- Differences and Similarities. Mater Sociomed. 2012;24(2):100-105. doi:10.5455/msm.2012.24.100-105. 


\author{
Abbreviations \\ GOLD- Global initiative of chronic Obstructive \\ Lung Disease \\ FEV1- Forced expiratory volume in first second \\ FVC-Forced vital capacity \\ PEFR-Peak expiratory flow rate \\ CAT score-COPD Assessment test \\ MMRC-Modified medical research council score
}

